\title{
Social Vulnerability Index: A Methodological Proposal for Application in the Cities of Barra do Garcas-MT, Pontal Do Araguaia-MT and Aragarcas-G0, Brazil
}

\author{
Greyce Bernardes de Mello Rezende \\ Department of Civil Engineering, Federal University of Mato Grosso, Barra do Garcas, Brazil \\ Email: greycebernardes@yahoo.com.br
}

How to cite this paper: de Mello Rezende, G.B. (2016) Social Vulnerability Index: A Methodological Proposal for Application in the Cities of Barra do Garcas-MT, Pontal Do Araguaia-MT and Aragarcas-GO, Brazil. Open Journal of Social Sciences, 4, 32-45.

http://dx.doi.org/10.4236/jss.2016.412004

Received: October 30, 2016

Accepted: December 3, 2016

Published: December 6, 2016

Copyright $\odot 2016$ by author and Scientific Research Publishing Inc.

This work is licensed under the Creative Commons Attribution International License (CC BY 4.0).

http://creativecommons.org/licenses/by/4.0/

\section{(c) (i) Open Access}

\begin{abstract}
The concept of vulnerability is intrinsically attached to the risks that can affect the balance of life in countless ways. Thus, this paper aimed to determine the sites that present social vulnerability levels in the urban context of the municipalities of Barra do Garcas-MT, Pontal do Araguaia-MT and Aragarcas-GO. The social vulnerability index was calculated using a set of 23 indicators, arranged in 05 subjects: Conditions of breadwinners, family conditions, housing conditions, urban infrastructure and economic dimension. Then these results were inserted in the geographic information system through ARCGIS program for spatial representation of social vulnerability levels. It was found that the social vulnerability indices found for the study area were very low, low and medium, which did not show a very critical situation. In Pontal do Araguaia-MT was found low level of vulnerability. In contrast, in Barra do Garcas-MT, the sectors with greater social vulnerability are located in the western part of the city, which includes neighborhoods with lower family income, and lack of infrastructure. Regarding the Aragarcas city was noted that the socio-territorial segregation of vulnerability is more evident, and the sectors with medium index of vulnerability are located more on the outskirts of the city. The proposed methodology was effective and the socio-economic dimension has been well addressed, which is a diagnostic path that can be used to search for a more efficient urban development through specific public policies, which in turn will increase the resilience of the population involved.
\end{abstract}

\section{Keywords}

Social Vulnerability, Methodology, Assessment, Indicators 


\section{Introduction}

It is clear that the urban expansion of Brazilian cities has been characterized by the segregation due to economic and social factors. This is reflected in territorial spreading represented by the occupations of the peripheries of the cities as well as irregular areas with high environmental vulnerability (riverbanks and hill slopes). Consequently, the densification of these areas is often devoid of the minimum urban infrastructure. It is true that urbanization can have negative effects observed from various angles, including: Environmental degradation, pollution, sealing, overexploitation of natural resources and the growing occupation of risk areas [1].

In this sense, in opposition to what the law provides, part of the population ends up taking areas where formal occupation is not permitted. There is a duality between "legal city", where public investments are concentrated and the "illegal" city, where quickly dominates the growth of informal occupations in poor and vulnerable environmentally areas [2].

In the example of these irregular occupations, it emphasizes that these are places of social exclusion, maintenance difficulties and organization of public spaces, of waterborne diseases brought by the floods. Occurs then, the peripheries and the occupation of the considered worst portions of the territory, subject to landslides and health risks [3].

Thus, real estate speculation in areas with large populations, because of the shortage of real estate, encourages the practice of irregular occupations by the low-income population that is sometimes excluded from the formal real estate market [4]. These occupations often occur in valley bottoms, subject to flooding, or hill slopes with great risk of slipping; besides polluted areas or areas of environmental protection, which only bring harm to the community.

In addition to real estate speculation, the maldistribution of wealth would integrate the origin of occupation process of environmental vulnerability areas. The high concentration of wealth creates a framework of social instability which is reflected in the organization of urban space [5]. Thus, the most deprived areas of infrastructure, services and quality of life are occupied by low-income people.

In this context, assess the social vulnerability of a group of individuals means assessing susceptibility and, indirectly, the responsiveness to natural hazards [6] [7]. In this sense, it should be made a diagnosis that identifies who is at risk, what is the risk, and in which location [8].

Therefore, this research aims to determine the sites that have social vulnerability levels in the urban context of the municipalities analyzed, through a set of 23 indicators, arranged in 05 themes. These indicators were obtained from the analysis of environmental vulnerability study models developed in Brazil, which were present in the census database of the Brazilian Institute of Geography and Statistics (IBGE) in 2010, with specified data by census tract.

In addition to this introductory content, this paper presents in their other items a theoretical foundation on vulnerability, materials and methods, results, considering the 
aspects related to the social dimension of vulnerability and conclusions generated by this study.

\section{Theoretical Conceptualization of Vulnerability}

Many authors [9] [10] [11] have undertaken efforts to elucidate the complexities associated with the concept of vulnerability, and some of them believe there is still a long way to go to reach a completely satisfactory concept that researchers can agree, as well as a solution that can be determined and applied in various situations and environments. This would be a challenge to interdisciplinarity, since the concept of vulnerability covers multiple dimensions and is a term used in various areas of knowledge, always related to the occurrence of phenomena that affect the conditions of human life, making it more fragile and susceptible to occurrence of events which disrupt their development [12].

The vulnerability meaning can therefore be understood from a variety of settings and applications [13], which are not always related but integrate aspects of risk, threats and risks in its definition [14]. One of these definitions, states that the vulnerability can be understood as the magnitude of the likely impact of a hazard on the targets, that is, its function is to measure harmful impacts of these events on affected targets [15]. In a more specific conception, vulnerability is defined as the probability of an individual, group or community being exposed and affected by situations of risk of various kinds, alone or in combination [12].

It is important to note that, in all cases, the authors agree that the vulnerability can be described as the set of characteristics which accentuate or mitigate the damage of these susceptible elements in consequences of extreme events [16].

It is noticed also that over the last few decades, the concept of vulnerability has evolved since it ceased to be identified only as the risk exposure to a much richer and complex concept that incorporates the characteristics of the affected elements that can accentuate or attenuate the potential impacts of an extreme event. Therefore, also focusing on the properties of the elements at risk, it is possible to go beyond the idea that the risk is up to an external factor and vulnerability begins to play an active role [17]. In this sense, the vision focused on physical occurrence is replaced by the view toward the catastrophe, which implicitly includes the elements that are potentially affected [18].

It is also important to note that the vulnerability has emerged as a key concept in the understanding of a system condition or their predisposition to be threatened by hazards [19]. Thus, system vulnerability is the ability of a system to withstand damage from external threats.

Following this understanding, the concept of vulnerability it is associated to resistance and resilience issues, understanding that resistance is the ability of an individual or group or even a society to continue working as usual after suffering a disaster. Already resilience would be the ability of an individual, group or society to recover from the impact of the disaster that has affected the normal operation [11] [20]. The two concepts can be related to the different attitudes to risk, because the resistance refers to 
a passive quality associated to the actual characteristics of the exposed elements and resilience refers to dynamic management associated with spontaneous or planned actions that affect the vulnerability.

Another relevant factor to be discussed is that the science of vulnerability requires an integrated approach to explain the complex interactions between social, natural and artificial systems. [21] Generally, what is found in most disaster research is that the risk of exposure to these disasters and evaluation of biophysical vulnerability are more emphasized [6] [22].

It is noted that social vulnerabilities are largely ignored, mainly because of the difficulty in quantifying them [6]. They would be partly a product of evolution of social inequalities, social and spatial segregation and social factors that influence or shape the susceptibility of various groups and also governing their responsiveness [6] [23]; and therefore the effects of disasters and catastrophes are extended [6].

Following the above, it is understood that it would be very important to analyze the conditions of vulnerability from the interaction of social and environmental problems, leading to socio-environmental vulnerability denomination which is the coexistence, cumulative or spatial overlap of poverty and social deprivation situations and exposure to risk situations/and or environmental degradation [24]. However, in this article we examine only the social vulnerability.

\section{Materials and Methods}

\subsection{Study Area}

The study area covers the urban area formed by three municipalities, namely: Aragarças, in Goiás; Pontal do Araguaia and Barra do Garças in Mato Grosso. Figure 1 shows the location of the study area.

Barra do Garçasis a municipality in the state of Mato Grosso, located in the mesoregion of Mato Grosso Southeast and micro region of Middle Araguaia. With a land area of 9078.983 square kilometers, has a population of 58,398 inhabitants [25] and a density of 6.23 inhabitants per square kilometer.

Pontal do Araguaia is also a municipality in the state of Mato Grosso, located in the middle region of Mato Grosso Southeast and micro region of Tesouro. With a land area of 2738.777 square kilometers, has a population of 6128 inhabitants [25] and a population density of 1.97 inhabitants per square kilometer.

Aragarças is a municipality in the state of Goiás, located in the middle region of the West of Goiás and micro region of Aragarças. With a land area of 662.91 square kilometers, has a population of 19,583 inhabitants [25] and a population density of 27.61 inhabitants per square kilometer.

For this study area were collected data available by IBGE and was applied the methodology proposed by the research, explained in the items below.

\subsection{Survey of Used Variables and Indicators}

To assess the social vulnerability of the study area and further development of an index 


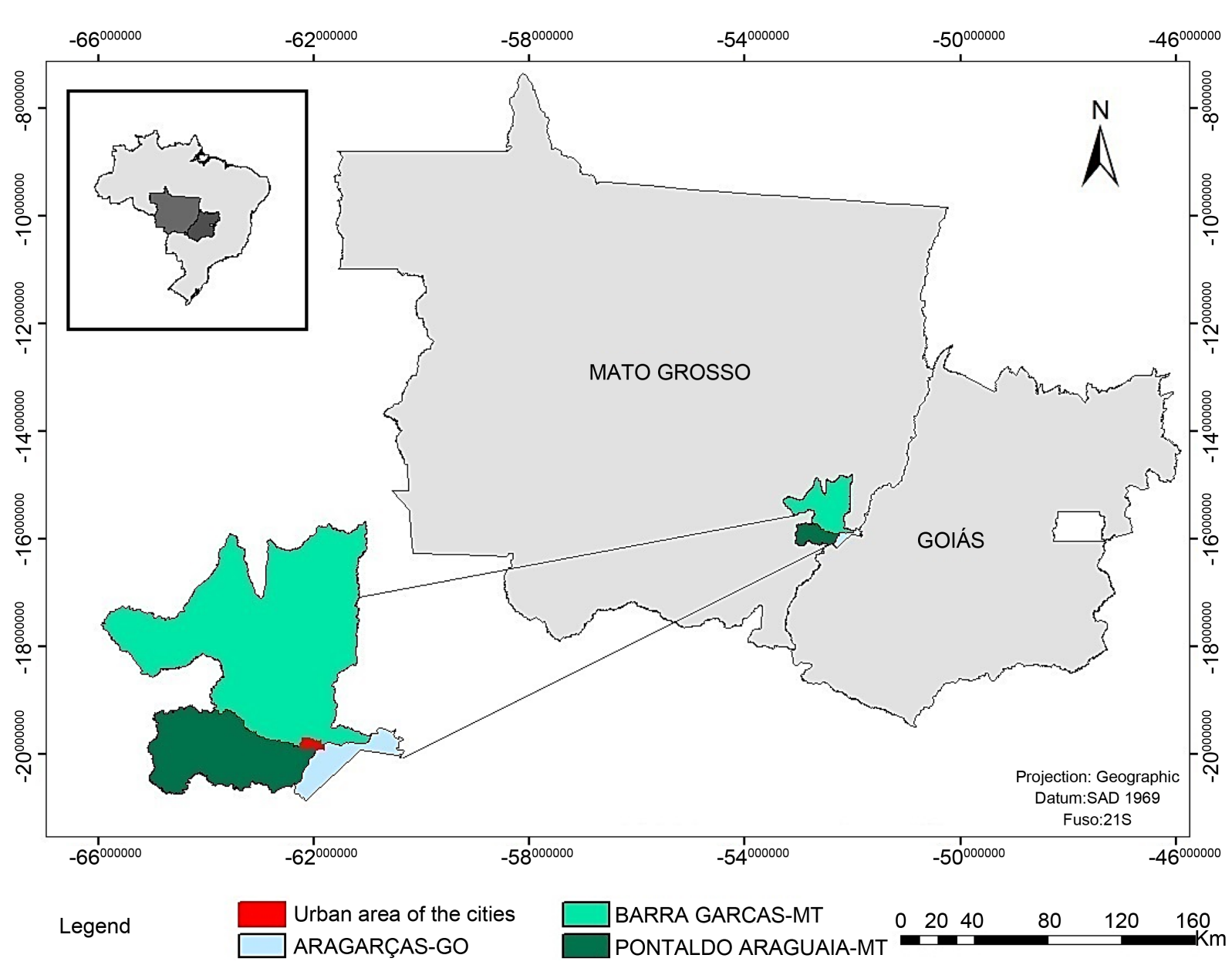

Figure 1. Location map of cities. Source: Elaborated by author.

2010 Census socioeconomic variables were collected from the Brazilian Institute of Geography and Statistics-IBGE [26]. For the cities of Barra do Garças, Aragarças and Pontal do Araguaia these data are only available by census tract, and therefore the smallest unit of analysis. There are 115 census tracts inserted in urban municipalities. (78 of Barra do Garças, 6 of Pontal do Araguaia and 31 in Aragarças).

For the selection of these variables were taken as reference Almeida [8], Gamba and Ribeiro [4] and Maior [27] models proposed; which work with socioeconomic and environmental indicators for the composition of the vulnerability index. Preference was given to those variables most repeated in the three models.

It is emphasized that the indicators were also chosen as availability of data for the cities studied, as well as to suit the reality of them. The characteristics of these indicators are related to social, economic, domiciliary infrastructure and urban infrastructure issues.

Therefore, 23 indicators were used, which, for applying more didactic, were grouped into homogeneous sub-groups, called factors and also in groups called dimensions. Were stipulated 5 dimensions that could contemplate the different aspects of social vulnerability, namely: The conditions of breadwinners, family conditions, economic 
conditions, the situation of the households, and finally the urban infrastructure available to these households (Table 1).

For the chosen indicators based justifications were made on the following criteria: 1) gender issue; 2) age and education (literacy), which are factors that influence negatively or positively in responsiveness to mobilization of assets; 3) performance issues, which hinder or facilitate the maintenance of the family; 4) age, characterized by greater dependence and vulnerability; 5) number of residents, as families with many components require greater assets; 6) home and urban infrastructure conditions, that reflect negative aspects of housing and basic sanitation, increasing the vulnerability of the residents.

Still according to Table 1 , these indicators have positivity or negativity relationship with the vulnerability, that is, contributing to its increase or decrease, and have different formulas for their calculation, as detailed in the following section.

Table 1. Representation of social vulnerability indicators for the study area.

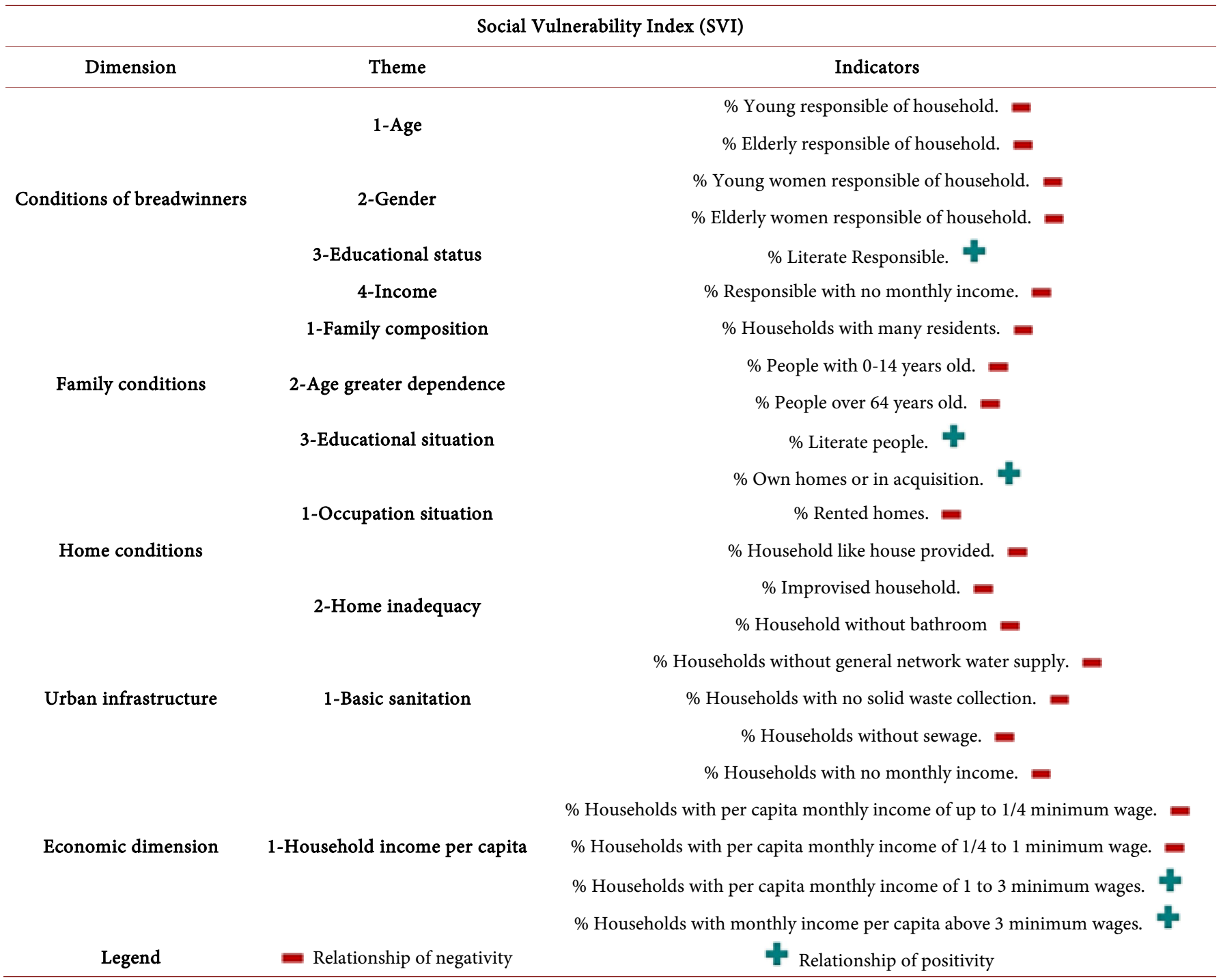

Source: Elaborated by author. 


\subsection{Data Analysis and Interpolating of Variables}

With the values of the variables collected, the calculations, followed the following steps:

Step 1: After choosing the set of variables, it was found that these showed different units of measurement. To facilitate the analysis, they were transformed into indexes that enabled aggregation in their dimensions to estimate the Social Vulnerability Index (SVI).

Step 2: It was necessary to classify how these variables are related to the vulnerability, that is, positively when the extent that the variable grows, it contributes to reduce the vulnerability; and negatively when the extent that the variable grows, it contributes to increase the vulnerability.

Step 3: After identifying the positive or negative relationship of variable with socioeconomic vulnerability process it was made operationalization to calculate the index from formulas that recognize these relationships and allow vulnerability analysis through the aggregation of all indexes. Such formulas are shown in Table 2.

At where:

$I=$ index calculated for each census tract of the study area

$x=$ observed value of each variable in each census tract

$m=$ minimum value identified in all census tracts

$M=$ maximum value identified in all census tracts

As can be seen, with this formula presented, it was necessary to have the minimum and maximum levels for each indicator. Therefore, a comparison of observed values was made in each of the census tracts always analyzed with the lowest and highest among all other sectors of the analyzed study area.

Step 4: After doing the calculation of the index for each indicator, the aggregation of these indices by size is performed by the arithmetic average, coming to the five dimensions index: conditions of breadwinners, family conditions, home conditions, urban infrastructure and economic dimension.

Step 5: Finally, the Social Vulnerability Index (SVI) of census tracts was calculated as the arithmetic average of the indexes of the five dimensions.

This procedure adjusts the observed values of the indices to scale which the minimum value is zero (0) and the maximum value is one (1) creating conditions for aggregation of these and subsequent estimation of Social Vulnerability Index (SVI) of the census tracts of Barra do Garças, Pontal do Araguaia and Aragarças.

For the representation of the indices for each variable group, we used a set of colors that correspond to the socially vulnerable levels of population explicit in each census tract studied. Table 3 shows the classification and representation of indexes ranging

Table 2. Formula indexes as the type of relationship (positive or negative).

\begin{tabular}{cc}
\hline When the relationship is positive: & When the relationship is negative: \\
$I=\frac{(M-x)}{(M-m)}$ & $I=\frac{(x-m)}{(M-m)}$
\end{tabular}

Source: Adapted from Maior (2014). 
Table 3. Classification and representation of indexes on social vulnerability levels.

\begin{tabular}{ccc}
\hline Index $(\mathbf{0}-\mathbf{1})$ & Social vulnerability levels & Coloring \\
\hline $1.0000-0.8001$ & Very high & \\
$0.8000-0.6001$ & High & \\
$0.6000-0.4001$ & Medium & \\
$0.4000-0.2001$ & Low & \\
$0.2000-0.0000$ & Very low \\
\hline
\end{tabular}

Source: Adapted from Maior (2014).

from $(0-1)$ for the corresponding color as a defined scale for this study:

Then these results were inserted in the geographic information system through ARCGIS program for possible spatial representation of social vulnerability levels.

\section{Results and Discussion}

The analysis of the dimensions of social vulnerability helped to demonstrate the current picture of the situation of population by census tract, revealing the main ills that affect families in the context of conditions of the breadwinners, family conditions, regarding to family composition, age structure and education, housing conditions, urban infrastructure, and economic situation; presenting the census tracts in which families are met negatively by the overlap of these factors within the socio-environmental vulnerability system.

As already mentioned, the result of social vulnerability index is obtained by the arithmetic average of the five dimensions worked, reflecting the census tracts that had higher rates, which can be seen on Figure 2 .

Based on the introduced map, it is possible to see the very low, low and medium vulnerability levels in the study area. At that point, it is shown the importance of public policies be adopted with a view to social development and to the satisfaction of the desires of the population.

From this result, it is verified that the city of Pontal do Araguaia-MT has a comfortable situation where all sectors were classified with low vulnerability. The city of Barra do Garças-MT was the only one to have sectors with very low level of vulnerability, but, on the other hand, presented five census tracts with medium level of vulnerability. The city of Aragarças also presented five census tracts with a medium level of vulnerability. Figure 3 shows the percentage of obtained indexes for each level of vulnerability.

As Figure 3, it can be observed that $9 \%$ of the sectors of the study area present medium vulnerability. The sectors that showed low vulnerability account for $83 \%$ of the total, and the sectors with very low vulnerability, represented only $8 \%$.

With these data, it is verified that in general the study area presents a comfortable position in relation to indexes shown.

Selecting the census tracts that had medium vulnerability indices in Figure 2 and their most critical indicators, it is possible to construct the Table 4, which summarizes the contribution indicators in each census tract with their respective number of indicators 


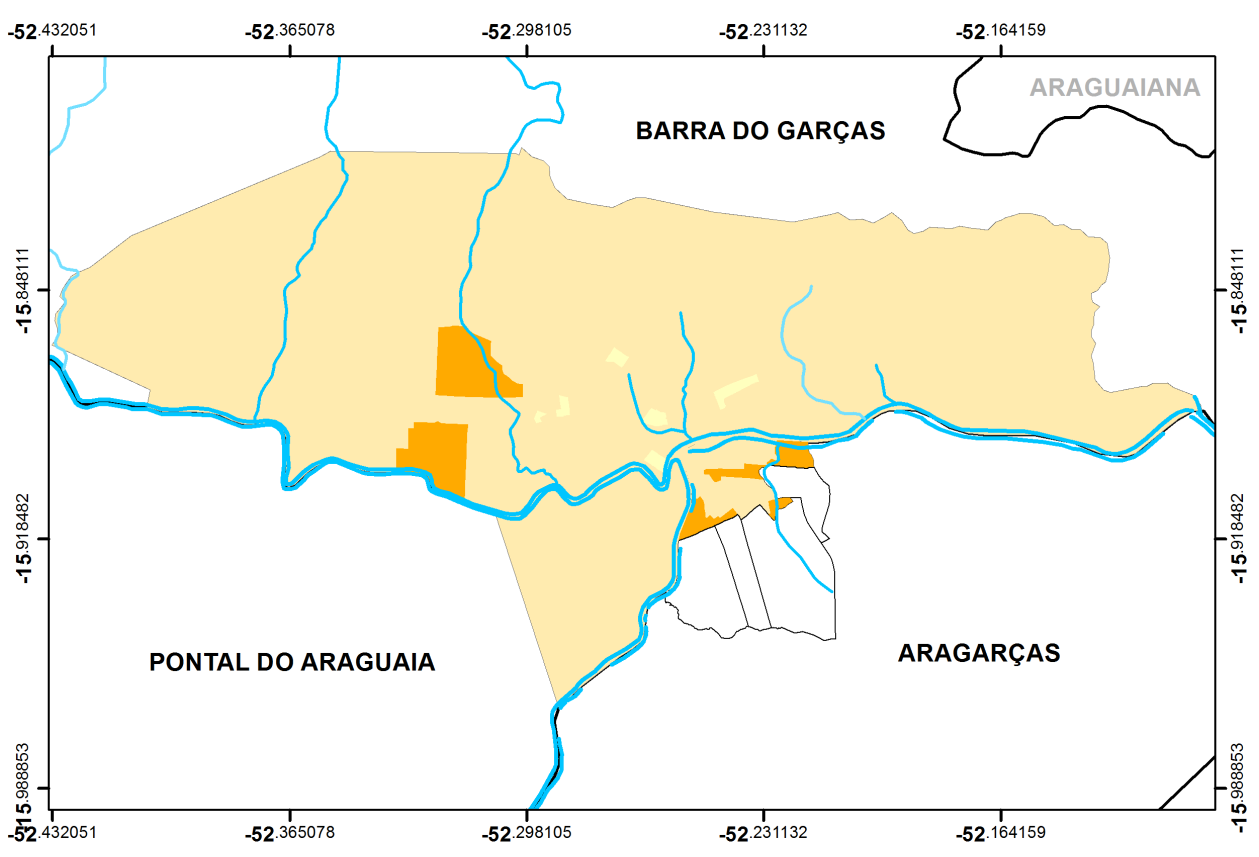

\section{Legend}

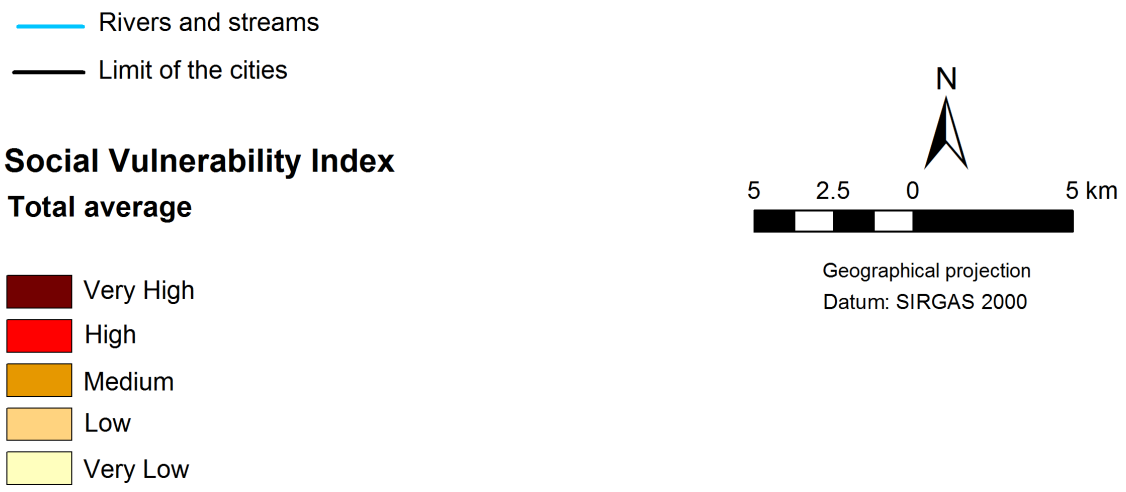

Figure 2. Social vulnerability. Source: Elaborated by author.

with very high and high vulnerability.

Analyzing Table 4 and Figure 2, it is verified that the greatest social vulnerability sectors are located in the western part of the city of Barra do Garças-MT and refer to neighborhoods Nova Barra, Jardim Palmares, Vila Maria and lots in BR 070. This last one is unique in its characteristics, since it is a sector with very few households (only 7), and other buildings refer to commercial buildings on the highway margins and the campus of the Federal University of Mato Grosso. In relation to the three sub-districts (Barra Nova, Palmares, and Vila Maria), notedly, they are neighborhoods with lower family income, poor infrastructure and are therefore socially vulnerable.

Regarding Aragarças-GO, the socio-territorial segregation of vulnerability is more present, and the sectors with medium index of vulnerability are located more on the outskirts of the city in the following districts: part of the Bela Vista Sector (the portion 


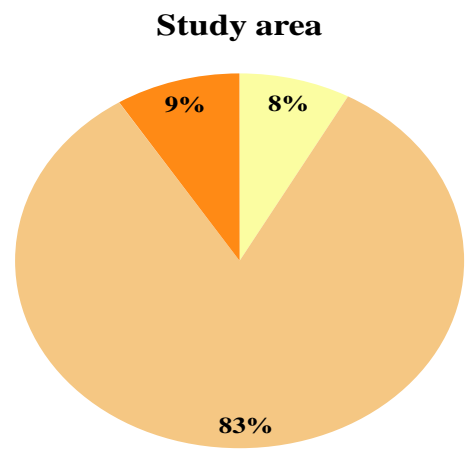

very low low medium

\section{Aragarças Barra do Garças Pontal do Araguaia}
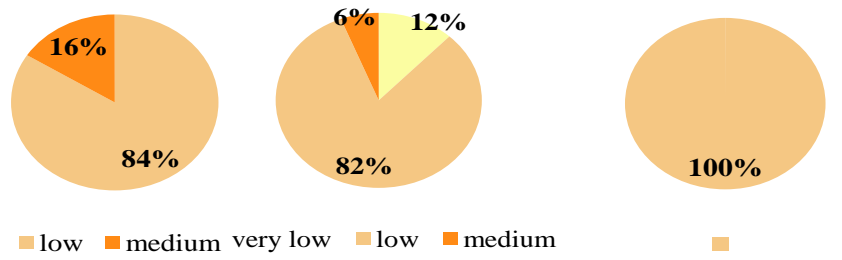

Figure 3. Percentage of census tracts according to the level of social vulnerability. Source: Elaborated by author.

Table 4. Summary of contributory indicators for social vulnerability by census tract.

\begin{tabular}{|c|c|c|c|c|c|c|c|c|c|c|}
\hline & \multicolumn{5}{|c|}{ Aragarças-GO } & \multicolumn{5}{|c|}{ Barra do Garças-MT } \\
\hline & 06 & 12 & 23 & 26 & 34 & 21 & 22 & 27 & 61 & 63 \\
\hline \multicolumn{11}{|l|}{ Young responsible of household } \\
\hline \multicolumn{11}{|l|}{ Elderly responsible of household } \\
\hline \multicolumn{11}{|l|}{ Young women responsible of household } \\
\hline \multicolumn{11}{|l|}{ Literate responsible } \\
\hline \multicolumn{11}{|l|}{ People with 0 - 14 years old } \\
\hline \multicolumn{11}{|l|}{ People over 64 years old } \\
\hline \multicolumn{11}{|l|}{ Literate people } \\
\hline \multicolumn{11}{|l|}{ Own homes or in acquisition } \\
\hline \multicolumn{11}{|l|}{ Household like house provided } \\
\hline \multicolumn{11}{|l|}{ Household without bathroom } \\
\hline \multicolumn{11}{|l|}{ Households without general network water supply } \\
\hline \multicolumn{11}{|l|}{ Households with no solid waste collection } \\
\hline \multicolumn{11}{|l|}{ Households without sewage } \\
\hline \multicolumn{11}{|c|}{ Households with per capita monthly income of $1 / 4$ to 1 minimum wage } \\
\hline \multicolumn{11}{|c|}{ Households with per capita monthly income of 1 to 3 minimum wages } \\
\hline \multicolumn{11}{|c|}{ Households with monthly income per capita above 3 minimum wages } \\
\hline Total indicators with very high vulnerability & 2 & 2 & 4 & 6 & 6 & 4 & 5 & 7 & 3 & 3 \\
\hline Total indicators with high vulnerability & 3 & 6 & 4 & 1 & 2 & 5 & 3 & 2 & 5 & 3 \\
\hline
\end{tabular}

Aragarças-GO 06: Part of Bela Vista sector (near to the airport). Aragarças-GO 12: José Divino Bispo and part of Ceará sector. Aragarças-GO 23: Alto Horizonte. Aragarças-GO 26: Part of Recanto das Primaveras. Aragarças-GO 34: Jardim das Palmeiras and Jardim Novo Mundo. Barra do Garças-MT 21: Nova Barra. Barra do Garças-MT 22: Vila Maria. Barra do Garças-MT 27: Lotes BR-070. Barra do Garças-MT 61: Vila Maria. Barra do Garças-MT 63: Nova Barra and JardimPalmares. Source: Elaborated by author. 
near the airport), José Divino Bispo Sector and part of Ceará Sector, Alto Horizonte, Jardim das Palmeiras, Jardim Novo Mundoand part of the Recanto das Primaveras. These last three neighborhoods are close to the Córrego Róla.

It is also necessary to give attention to indicators which alone showed high to very high indexes of vulnerability. The analysis of indicator by indicator separately generated the elaboration of Figure 4 which shows the indicators with the highest percentages of high and very high vulnerability in the study area, as well as their respective dimension.

It is verified that the most critical dimension is the economic dimension, with two indicators with high vulnerability percentages, showing that the income factor is something to be worked in the municipalities in question. In this way, incentives to professional courses and better education for greater access to universities, as well as encouragements to industry and service companies to increase employment can be solutions for vulnerable populations.

Households with many residents and households without sanitation were also indicators with high percentages, respectively $57.7 \%$ and $50.4 \%$ of the census tracts. Other indicators: rented households and young responsible of household, even with the highest levels of its dimensions, did not have critical values: $14.4 \%$ and $13.5 \%$ of the census tracts, respectively.

Given this diagnosis, even if the results presented are not critical it is necessary to implement public policies in vulnerable areas for the social development is full throughout the study area. It is believed that this indicator methodology can certainly guide future public policy which should always be based on the characteristic features of each sector.

\section{Indicators}

Young responsible of household

Households with many residents

Rented homes

Households without sewage

Households with per capita monthly income of $1 / 4$ to 1 minimum wage

Households with monthly income per capita above 3 minimum wages

Dimensions
$13.50 \%$

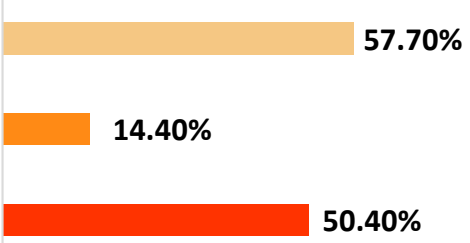

$49.50 \%$
Conditions of breadwinners

Family conditions
Home conditions

Urban infrastructure

Figure 4. Percentage of high and very high vulnerability indexes and their dimensions. Source: Elaborated by author. 


\section{Conclusions}

This study has shown the level of vulnerability in urban areas of the municipalities of Aragarças-GO, Barra do Garças-MT and Pontal do Araguaia-MT, specifying in each census tract of the vulnerability index of its residents.

The social vulnerability indexes found for the study area were very low, low and medium, which did not show a very critical situation. This is because of the three cities analyzed, only Aragarças-GO and Barra do Garças-MT showed medium levels of vulnerability.

In Barra do Garças-MT, the sectors with greater social vulnerability are located in the western part of the city, which includes neighborhoods with lower family income, and poor infrastructure. Regarding Aragarças-GO it was observed that the socio-territorial segregation of vulnerability is more present, and the sectors with medium index of vulnerability are located more on the outskirts of the city.

At this point, it is demonstrated the importance of public policies to be adopted with a view to social development and care of people's aspirations.

It is therefore found that the proposed methodology was effective and the socioeconomic dimension has been well addressed, covering the main aspects that can increase the vulnerability process of the study area families, which is a diagnostic path that can be used in search more efficient urban development, minimizing the socioterritorial segregation in cities involved.

\section{References}

[1] D’ercole, R., Hardy, S., Metzger, P. and Robert, J. (2009) Vulnérabilités Urbaines Dans les Pays Andins: Introduction générale. Bulletin de PInstitut Français d Études Andines, 38, 411-420. http://horizon.documentation.ird.fr/exl-doc/pleins_textes/divers13-12/010049894.pdf https://doi.org/10.4000/bifea.2227

[2] Maricato, E. (2001) Brasil, cidades: Alternativas para a crise urbana. Vozes, Petrópolis.

[3] Kahtouni, S. (2004) Cidade das águas. RiMa, São Carlos.

[4] Gamba, C. and Ribeiro, W.C. (2012) Indicador e avaliação da vulnerabilidade socioambiental no município de São Paulo. GEOUSP - Espaço e Tempo, 31, 19-31. https://doi.org/10.11606/issn.2179-0892.geousp.2012.74266

[5] Ribeiro, W.C. (2010) Riscos e vulnerabilidade urbana no Brasil. Scripta Nova, 14, 65. http://www.ub.es/geocrit/sn/sn-331/sn-331-65.htm

[6] Cutter, S.L., Boruff, B.J. and Shirley, W.L. (2003) Social Vulnerability to Environmental Hazard. Social Science Quarterly, 84, 242-261. https://doi.org/10.1111/1540-6237.8402002

[7] Cutter, S.L. and Finch, C. (2008) Temporal and Spatial Changes in Social Vulnerability to Natural Hazards. Proceedings of the National Academy of Sciences, 105, 2301-2306. http://www.pnas.org/cgi/doi/10.1073/pnas.0710375105 https://doi.org/10.1073/pnas.0710375105

[8] Almeida, L.Q. (2010) Vulnerabilidades socioambientais de rios urbanos: Bacia hidrográfica do rio Maranguapinho, região metropolitana de Fortaleza. Ph.D. Dissertation, Universidade Estadual Paulista, Rio Claro.

[9] Wisner, B., Blaikie, P., Cannon, T. and Davis, I. (1994) At Risk: Natural Hazards, People’s 
Vulnerability and Disasters. Routledge, Londres. https://doi.org/10.4324/9780203428764

[10] Veyret, Y. and Reghezza, M. (2006) Vulnérabilité et risques L'approche récente de la vulnérabilité. Responsabilité \& Environnement, 43, 9-13. http://www.annales.org/re/2006/re43/Veyret.pdf

[11] Dauphiné, A. and Provitolo, D. (2007) La résilience: Un concept pour la gestion des risques. Annales de Géographie, 654, 115-125. https://doi.org/10.3917/ag.654.0115

[12] Pessoa, Z.S. (2012) A metrópole periférica: Identidade e vulnerabilidade socioambiental na região metropolitana de Natal-RN/Brasil.Ph.D. Dissertation, Universidade Estadual de Campinas, Campinas.

[13] Cutter, S.L. (1996) Vulnerability to Environmental Hazards. Progress in Human Geography, 20, 529-539. https://doi.org/10.1177/030913259602000407

[14] Marandola, E. and Hogan, D.J. (2004) O risco em perspectiva: Tendências e abordagens. Geosul, 19, 25-58. https://periodicos.ufsc.br/index.php/geosul/article/view/13431/12328

[15] Veyret, Y. (Org.) (2007) Os riscos: O homem como agressor e vítima do meio ambiente. Contexto, São Paulo.

[16] Masgrau, L.R. and Palom, A.R. (2012) Flood Vulnerability and Commercial Activities: The Case of the City of Girona, Spain. Disasters, 36, 676-699. https://doi.org/10.1111/j.1467-7717.2012.01277.x

[17] Reghezza, M. (2006) La vulnérabilité: Un concept problématique. In: Leone, F. and Vinet, F., Eds., La vulnérabilité des sociétés et des territoires face aux menaces naturelles, Publications de l'Université Paul-Valéry Montpellier III, Montpellier, 35-39.

[18] White, G.F., Kates, R.W. and Burton, I. (2001) Knowing Better and Losing Even More: The Use of Knowledge in Hazards Management. Environmental Hazards, 3, 81-92. https://doi.org/10.3763/ehaz.2001.0308

[19] Lee, Y.-J. (2014) Social Vulnerability Indicators as a Sustainable Planning Tool. Environmental Impact Assessment Review, 44, 31-42. https://doi.org/10.1016/j.eiar.2013.08.002

[20] Pelling, M. (2003) The Vulnerability of Cities: Natural Disasters and Social Resilience. Earthscan Publications, London.

[21] Cutter, S.L. (2003) The Vulnerability of Science and the Science of Vulnerability. Annals of the Association of American Geografhers, 93, 1-12.

[22] Turner, B.L., et al. (2003) Illustrating the Coupled Human-Environment System for Vulnerability Analysis: Three Case Studies. Proceedings of the National Academy of Sciences of the United States of America, 100, 8080-8085.

http://www.pnas.org/content/100/14/8080.full https://doi.org/10.1073/pnas.1231334100

[23] Kaztman, R. (2001) Seducidos y abandonados: El aislamiento social de los pobres urbanos. Revista de la CEPAL, 75, 171-189. http://repositorio.cepal.org/bitstream/handle/11362/10782/075171189_es.pdf?sequence=1

[24] Alves, H.P., Alves, C.D., Pereira, M.N. and Monteiro, A.M.V. (2010) Dinâmicas de urbanização na hiperperiferia da metrópole de São Paulo: Análise dos processos de expansão urbana e das situações de vulnerabilidade socioambiental em escala intraurbana. Revista Brasileira de Estudos de Populacionais, 7, 141-159. https://doi.org/10.1590/S0102-30982010000100009

[25] Instituto Brasileiro de Geografia e Estatística (IBGE) (2015) População estimada. http://www.cidades.ibge.gov.br/xtras/perfil.php

[26] Instituto Brasileiro de Geografia e Estatística (IBGE) (2010) Censo demográfico brasileiro. http://www.ibge.gov.br 
[27] Maior, M.M.S. (2104) Vulnerabilidade socioambiental e o processo de transbordamento urbano: Uma Proposta de Metodologia para Análise das suas Relações. PhD Dissertation, Universidade Federal de Campina Grande, Campina Grande.

Submit or recommend next manuscript to SCIRP and we will provide best service for you:

Accepting pre-submission inquiries through Email, Facebook, LinkedIn, Twitter, etc. A wide selection of journals (inclusive of 9 subjects, more than 200 journals)

Providing 24-hour high-quality service

User-friendly online submission system

Fair and swift peer-review system

Efficient typesetting and proofreading procedure

Display of the result of downloads and visits, as well as the number of cited articles

Maximum dissemination of your research work

Submit your manuscript at: http://papersubmission.scirp.org/

Or contact jss@scirp.org 